\title{
FONTINALIS DICHELYMOIDES (FONTINALACEAE, BRYOPHYTA), A NEW SPECIES FOR THE MOSS FLORA OF RUSSIA
}

\section{FONTINALIS DICHELYMOIDES (FONTINALACEAE, BRYOPHYTA) - НОВЫЙ ВИД ДЛЯ БРИОФЛОРЫ РОССИИ}

\author{
ANATOLY I. MAKSIMOV ${ }^{1}$, ALINA V. FEDOROVA ${ }^{2} \&$ MiCHAEL S. IGNATOV $^{2,3}$ \\ АНАТОЛИЙ И. МАКСИМОВ ${ }^{1}$, АЛИНА В. ФЕДОРОВА ${ }^{2}$, МИХАИЛ С. ИГНАТОВ ${ }^{2,3}$ \\ Abstract \\ Fontinalis dichelymoides is newly recorded for the moss flora of Russia; it was found in the course \\ of revising herbarium collections of Fontinalis squamosa. The description and illustration of $F$. \\ dichelymoides based on the specimen from Russia are given; key to identification of a group of close \\ species, including $F$. dichelymoides, $F$. squamosa and $F$. dalecarlica, is provided. The results of mo- \\ lecular studies of Fontinalis specimens from Russia are commented. \\ Резюме \\ В результате ревизии гербарных образцов Fontinalis squamosa был обнаружен новый вид \\ для флоры мхов России Fontinalis dichelymoides. Приводится описание вида, рисунок и ключ для \\ различения близких видов, F. dichelymoides, F. squamosa и F. dalecarlica. Комментируются \\ результаты молекулярных исследований.
}

KEYWORDS: Fontinalis dichelymoides, distribution, Russia

\section{INTRODUCTION}

The taxonomy of the genus Fontinalis remains poorly known, as these aquatic mosses are extremely variable. In Russia in most publications of 20th century, as well as in the last checklist of mosses, only four species were reported: F. antipyretica Hedw., F. hypnoides Hartm., F. squamosa Hedw. and F. dalecarlica Bruch, Schimp. \& W. Gümbel (Abramova et al., 1961; Ignatov et al., 2006), which is similar to most European countries. At the same time, in older literature, e.g. Limpricht (1896) and Brotherus (1923), more than 10 species of the genus were accepted; however subsequent revision of Welch (1960) reduced most of them to synonymy. Among others, $F$. dichelymoides Lindb. was synonymized with $F$. dalecarlica, and for a certain time remained in oblivion.

Fontinalis dichelymoides was described by Lindberg (1869) from Piojärvi Lake in Finland by collection of Brotherus. It seems to be a rare species, as much later, in "Die Laubmoose Fennoskandias", Brotherus (1923) added to the type locality only one collection from Sweden and three from Finland. Nyholm (1960) thought that $F$. dichelymoides is merely a lake form of $F$. dalecarlica, likely influenced by Welch opinion.
The first authors who returned $F$. dichelymoides as a species were Koponen et al. (1977), but the European checklist (Corley et al., 1981) and the catalogue of species distribution (Duell, 1984) ignored this, continuing keeping this species as a synonym of $F$. dalecarlica. With time, however, the status of $F$. dichelymoides was accepted by Scandinavian bryologists (Koponen et al., 1995; Söderström, 1996; Ulvinen \& Syrjänen, 2009, Hedenäs et al., 2014) and in new European checklist (Hill et al., 2006). The rarity of the species was confirmed, as Ulvinen \&. Syrjänen (2009) reported it from only eight provinces of Finland, from the south to Lapland, and there are only eight dots on the map of its distribution in Sweden (Hedenäs et al., 2014).

To complete the history of the previous studies of $F$. dichelymoides, the species was reported by Welch (1934) in North America; however, in the recent treatment of Allen (2014) it is placed in synonymy of $F$. sullivantii Lindb.

In the course of revision of Fontinalis collections in herbarium of Petrozavodsk (PTZ), F. dichelymoides was identified from Karelia; it was found among specimens kept under F. squamosa Hedw. Along with this first record

\footnotetext{
1 - Institute of Biology of Karelian Research Centre, Russian Academy of Sciences, Pushkinskaya 11, Petrozavodsk, 185910 Russia - Россия 185910 Петрозаводск, ул. Пушкинская, 11, Институт биологии Кар НЦ РАН; e-mail: maksimov tolya@mail.ru

2 - Tsitsin Māin Botanical Garden, Russian Academy of Sciences, Botanicheskaya Str., 4, Moscow 127276 Russia - Poccия 127276 Москва, Ботаническая 4, ГБС РАН; e-maila: alina 77777@mail.ru \& misha ignatov@list.ru

3 - Lomonosov Moscow State University, Biological Faculty, Geobotany Dept., Leninskie Gory Str. 1-12, Moscow 119234 Russia - Россия, 119234, Москва, Ленинские Горы, д. 1 стр. 12, Московский государственный университет, биологический факультет, кафедра геоботаники.
} 
of the species in Russia, we were able to check its status by molecular markers.

\section{MATERIAL AND METHODS}

Specimens and DNA markers: as the expanded set of Fontinalis is available in GenBank from the study of Shaw \& Allen (2000), we used their data, supplemented with several specimens of superficially similar species from Karelia. Nuclear ITS and chloroplastic trnL-F markers were used, as they were used by Shaw \& Allen (2000), and proved to be useful for pleurocarp phylogeny studies (Gardiner et al., 2005). Total genomic DNA was extracted from dry plants using the Nucleospin Plant Extraction Kit (Macherey-Nagel, Germany). The laboratory protocols were essentially the same as in the latter publication.

Phylogenetic analysis. Sequences were aligned by Clustal and modified manually using BioEdit 7.0 (Hall, 1999). Bayesian analysis of the ITS dataset was conducted in MrBayes (Huelsenbeck \& Ronquist, 2001) using the GTR + G model. It was run for 10000000 generations with sampling every 1000 generations. The first $25 \%$ of sampled trees were discarded for the burn-in. Supplementary maximum parsimony analysis was performed in Nona (Goloboff, 1994) in Winclada shell (Nixon, 1999).

\section{RESULTS}

ITS sequences were found to be variable enough, and both Bayesian and MP analyses resulted in a resolved phylogenetic tree with some insufficient differences, so only Bayesian tree is shown with MP bootstrap values inserted.

The tree is rooted on Brachelyma, and, predictably, Dichelyma is the next in a grade to Fontinalis. Then Fontinalis antipyretica clade (most specimens) [and the only specimen of $F$. squamosa included in our dataset], branches off. The next branch combines $F$. hypnoides, $F$. gracilis (accepted here as a species), and one specimen of $F$. antipyretica. The terminal clade, called here "Fontinalis dalecarlica-clade" (Fig. 1), includes F. dalecatlica, many American endemic species, and also $F$. dichelymoides. Fontinalis reafearnii keeps the basalmost position, but the clade of $F$. reafearnii + all others members of " $F$. dalecarlica-clade" has support only in Bayesian analysis. The " $F$. dalecarlica-clade" without $F$. readfearnii however received sufficient support in both analyses.

Fontinalis dichelymoides has a sister position to all other species of " $F$. dalecarlica-clade": F. missourica, $F$. flaccida, F. sullivantii, F. welchiana, F. novae-angliae and $F$. dalecarlica. They form polytomy with smaller clades without support, thus their grouping is not worthy a discussion.

Sequences of trnL-F were found to be much less variable than ITS, although their phylogenetic analysis divides the genus into two clades: " $F$. dalecarlica-clade" and $F$. antipyretica $+F$. hypnoides-clade (or grade), without support.

Fontinalis dichelymoides obviously is a member of "F. dalecarlica-clade" and has no one substitution in
Table 1. Number of substitutions + indels between $F$. dichelymoides and some other Fontinalis species

$\begin{array}{lll} & \text { trnL-F } & \text { ITS } \\ \text { F. novae-angliae AF191540 / AF192131 } & 0 & 6+1 \\ \text { F. dalecarlica - / Karelia } & - & 6+1 \\ \text { F. dalecartica AF191534 / AF192125 } & 0 & 14.5+1 \\ \text { F. sullivantii AF191521 / AF192112 } & 1 & 7+1 \\ \text { F. sullivantii AF191511 / AF192102 } & 1 & 8+1 \\ \text { F. welchiana AF191541 / AF192133 } & 1 & 7+7 \\ \text { F. missourica AF191515 / AF192106 } & 2 & 9+2 \\ \text { F. flaccida AF191513 / AF192104 } & 5 & 15+1 \\ \text { F. redfearnii AF191507 / AF192098 } & 5 & 22+1 \\ \text { F. squamosa AF191520 / AF192111 } & 10 & 22 \\ \text { F. hypnoides AF191508 / AF192130 } & 10 & 18+1 \\ \text { F. antiperetica AF191516 / AF192117 } & 15 & 23+4\end{array}$

trnL-F compared with $F$. novae-angliae and $F$. dalecarlica, which, however. markedly differ from $F$. dichelymoides by ITS. The difference in ITS between $F$. dalecarlica (Karelian) and $F$. dichelymoides is much greater (six substitutions and one indel) than between $F$. dalecarlica (Karelian) and F. novae-angliae (one substitution) and between F. dalecarlica (Karelian) and F. sullivantii (two substitutions).

\section{TAXONOMY}

The above mentioned differences do not provide support by statistical methods of phylogenetics, but the fact that three specimens of $F$. dalecarlica from Karelia are not variable in ITS indicates that $F$. dichelymoides is better differentiated genetically than some other members of "F. dalecarlica-clade" and, along with morphological differences, merits a status of species of its own. Its description based on Russian specimens is provided below.

Fontinalis dichelymoides Lindb., Öfvers. Fin. Vet. Soc. Förhandl. 12: 76. 1869.

Fig. 2

Plants soft, glossy, yellowish in distal part and darkbrown below; stems thin, 6-15 cm long, covered with leaves in lower portion or with partially destroyed leaves; subpinnately branched; branches loosely arranged, patent, secund, 4.9-15 cm long, slightly attenuate and curved at tips. Stem leaves loosely arranged, ca. $1 \mathrm{~mm}$ apart; straight or curved, firm, narrowly lanceolate, decurrent, slightly concave, narrowly acute, often tubulose-subulate distally, 3.8-5.8 mm long, 0.6-1.0 mm wide, with length: width ratio $5.5-8.7$ :1; slightly overlapping, forming $20^{\circ}-30^{\circ}$ angle with the stem; margins slightly recurved at places, entire or obscurely denticulate at apex. Median leaf cells linear, 120-210(-260) $\mu \mathrm{m}$ long, 12-15 $\mu \mathrm{m}$ wide, with length: width ratio 11-17.5:1. Alar cells enlarged, hyaline to yellowish or brownish, rectangular or almost hexagonal, slightly inflated, forming clearly differentiated alar group; cells in mid-leaf between alar groups short, thick-walled, with dark or orange-colored cell walls, together with dark alar groups making basal part of leaf darker than its distal part; leaf lamina is often constricted above alar groups. Gametangia and sporophytes absent in collection from Russia. 


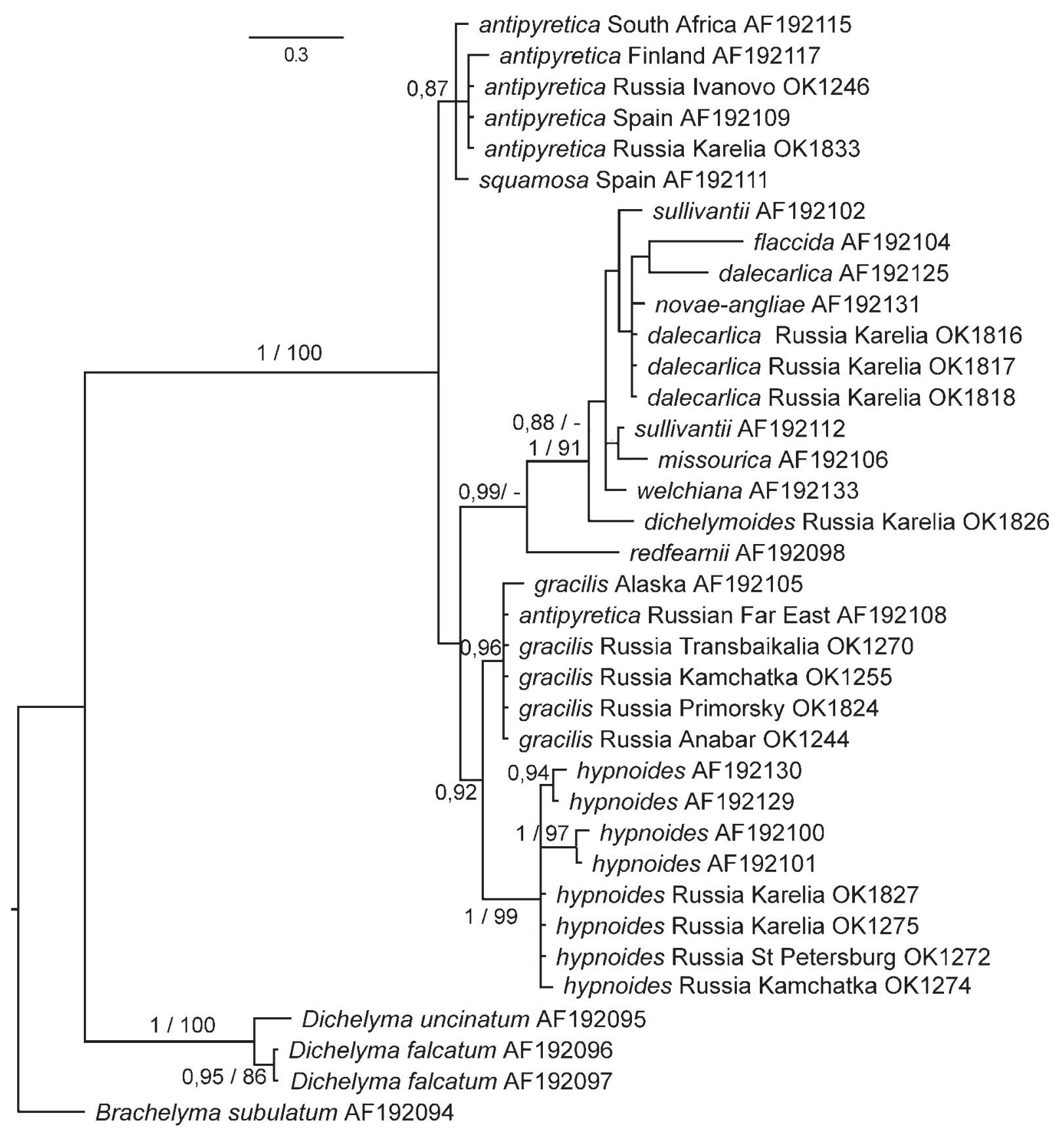

Fig. 1. Bayesian tree, showing position of Fontinalis dichelymoides in F. dalecarlica-clade. Posterior probabilities above 0.80 are shown at branches. Low posterior probablilites, $<0.80$ and bootstrap values $<70$ are not shown.

In Karelia Fontinalis dichelymoides was collected in the lake Nizhnee Ladwo, near the shore. Brotherus (1923) also mentions that this species occasionally grows on tree roots in stagnant water.

Differentiation. The habitat of Fontinalis dichelymoides is stagnant water, and this alone allows its differentiation in the field from $F$. squamosa and $F$. dalecarli$c a$. Also, F. dichelymoides has the relatively longer leaves compared with these two species; their length to width ratio is 5.5-8.7:1, whereas it is 3.6-5.0:1 in F. squamosa and 3.2-4.4:1 in F. dalecarlica.

In leaves of $F$. dichelymoides marginal border is weak- ly differentiated or absent ( $0-1$ cells wide), whereas in $F$. squamosa leaves have a clear marginal border $1-2$ cells wide and in F. dalecarlica even better differentiated, 25 cells wide.

\section{KEY TO IDENTIFICATION OF THE SPECIES OF FONTINALIS WITH CANALICULATE LEAVES}

1. Tufts compact, formed of densely entangled, not secund shoots, often with numerous sporophytes; stem leaves concave, lanceolate, acute, $1.8-2.8 \times 0.4-0.6$ $\mathrm{mm}$, with lendth: width ratio 3.6-5: 1; differentiated marginal cells in 1-2 rows (best seen in leaf trans- 


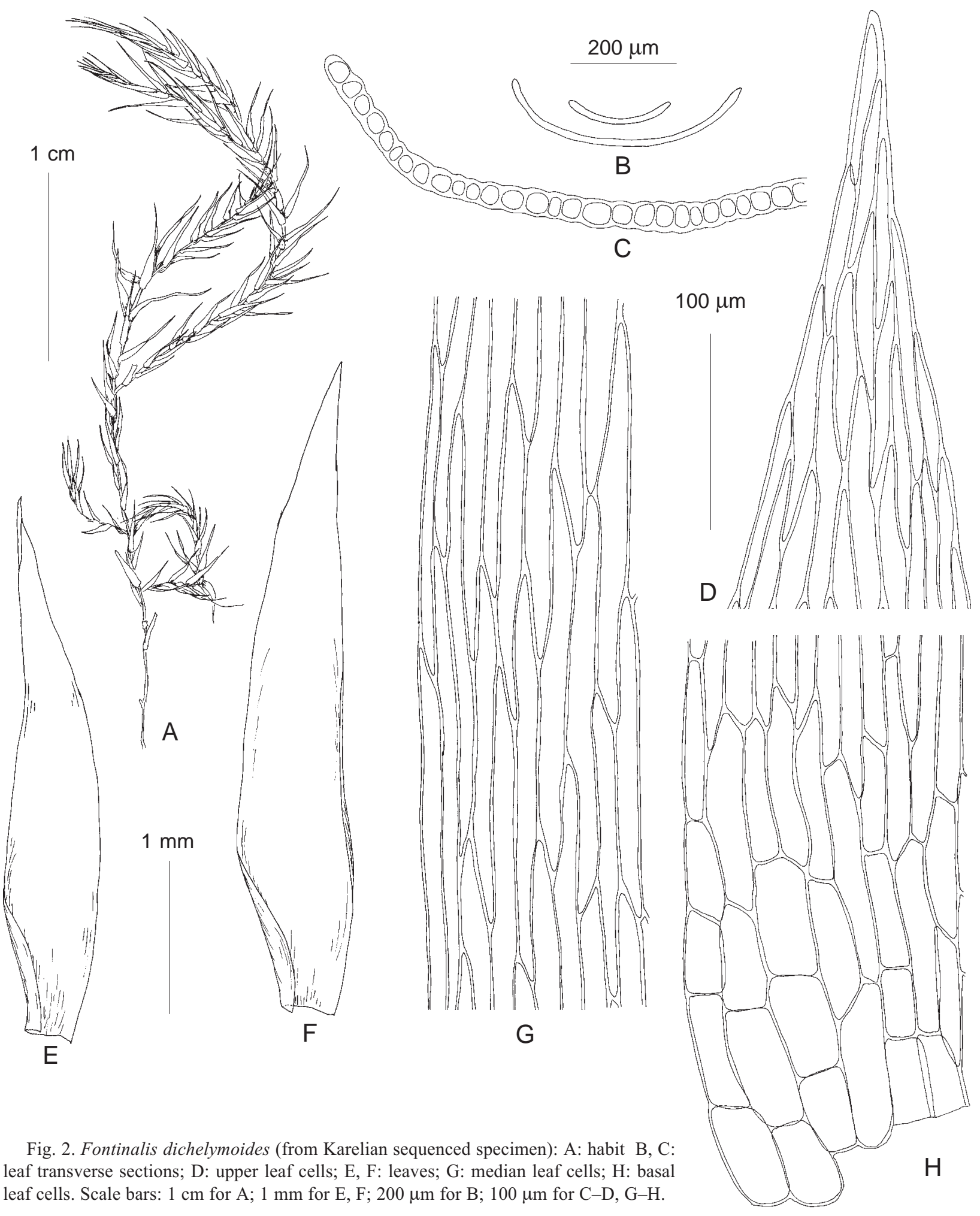

verse section); median leaf cells 90-135× 11.2-14 $\mu \mathrm{m}, 6.8-9.3: 1$; cell walls weakly thickened.

F. squamosa

- Tufts loose, stems and branches secund; sporophytes rare; stem leaves canaliculate; median leaf cells 712(-15) $\mu \mathrm{m}$ wide
2. Stem leaves narrowly lanceolate to linear, long acuminate, occasionally tubulose at apices, 3.8-5.8 $\times 0.6-1.0 \mathrm{~mm}$, with length: width ratio 5.5-8.7:1; differentiated marginal cells in 0-1 rows; median leaf cells 129-210×12-15 $\mu \mathrm{m}, 11-17.5: 1$; cell walls weakly thickened 
Table 1. Specimen used in molecular phylogenetic analyses, with GenBank accession numbers.

Species Vaucher, including herbarium acronym

Fontinalis antipyretica Fontinalis antipyretica Fontinalis dalecarlica Fontinalis dalecarlica Fontinalis dalecarlica Fontinalis dichelymoides Fontinalis gracilis Fontinalis gracilis Fontinalis gracilis Fontinalis gracilis Fontinalis hypnoides Fontinalis hypnoides Fontinalis hypnoides Fontinalis hypnoides
Russia, Ivanovo 4 July 2012 Sorokin \& Golubeva sn (MHA) Russia, Karelia, Maksimov (PTZ 2634)

Russia, Karelia, Maksimov (PTZ 2657)

Russia, Karelia Maksimov (PTZ 2664)

Russia, Karelia Maksimov (PTZ 2652)

Russia, Karelia, Boichuk (PTZ 4745)

Russia, Zabaikalsky, Bazarova sn 15.IX.2015 (MHA)

Russia, Kamchatka, 20 July 2004 Czernyasjeva sn (MHA)

Russia, Primorsky Ignatov 06-3366 (MHA)

Russia, Anabar Plateau, Fedosov 08-287 (MHA)

Russia, Karelia Maksimov (PTZ 24747)

Russia, Karelia Boichuk sn, 10.VII.2000 )LE)

Russia, Leningrad, Leushina sn, 7.VIII.2005 (LE)

Russia, Kamchatka, Czernyadjeva, 31.VII.2004 \#29 (LE)

\author{
Extraction
}

GenBank \#
ITS trnL-F
MK330647

OK1246

OK1833

OK1816

OK1817

OK1818

OK 1826

OK 1270

OK1255

OK1824

OK1244

OK 1827

OK1275

OK 1272

OK1274
MK330649

MK330638

MK330639

MK330640

MK330637 MK330933

MK330645

MK330646

MK330648

MK330650

MK330641

MK330642

MK330643

MK330644
- Stem leaves_lanceolate, acute, margins incurved in proximal part, $2.9-3.3 \times 0.7-1.0 \mathrm{~mm}$, with length: width ratio $3.2-4.4: 1$; differentiated marginal cells in 2-5(-6) rows; median leaf cells $90-171 \times 8-14 \mu \mathrm{m}$, 7.5-14:1; cell walls strongly thickened

F. dalecarlica

Specimens examined: RUSSIAN EUROPEAN NORTHWEST: Republic of Karelia: National park "Kaleval'sky", vicinity of Ladvozero Village, Nizhnee (Lower) Ladvozero Lake, an island behind the dam $\left(64^{\circ} 49^{\prime} \mathrm{N}, 2^{\circ} 52^{\prime} \mathrm{E}\right)$, in water near the shore, 10.VIII.1997, Boychuk s.n. (PTZ 4745); same place, 17.VIII.1997, Boychuk s.n. (PTZ 4746).

\section{AKNOWLEDGEMENTS}

Authors cordially thank M.A. Boychuk for for providing her collections for our study, T.A. Maksimova for the help with laboratory studies of the material and E.A. Ignatova for preparing illustration. Work of Maksimov was supported by state institutional project №0221-20170048, of Fedorova by state institutional project №118021490111-5 and of Ignatov by RSF №18-14-00121.

\section{LITERATURE CITED}

[ABRAMOVA, A.L., L.I. SAVICZ-LJUBITSKAYA \& Z.N. SMIRNOVA] АБРАМОВА А.Л., Л.И. САВИЧ-ЛЮБИЦКАЯ, З.Н. СМИРНОBA 1961. Определитель листостебельных мхов Арктики СССР.[Handbook of mosses of Arctic of the USSR] Л., Изд-во АН СССР [Leningrad, Izd. Akad. Nauk SSSR], $716 \mathrm{pp}$.

ALLEN, B.H. 2014. Fontinalaceae. - In: Flora of North America Editorial Committee (eds.) Flora of North America North of Mexico 28: 489-501.

BROTHERUS, V. F. 1923. Die Laubmoose Fennoskandias - Flora Fennica 1: 1-635.

CORLEY, M.F.V., A.C. CRUNDWELL, R.DÜLL, M.O. HILL \& A. J. E. SMITH. 1981. Mosses of Europe and the Azores: an annotated list of species, with synonyms from the recent literature. - Journal of Bryology 11: 609-689.

DUELL, R. 1983. Distribution of the European and Macaronesian Liverworts (Hepaticophytina). - Bryologische Beitraege 2: 115 pp.

GARDINER, A., M. IGNATOV, S. HUTTUNEN \& A. TROITSKY. 2005. On resurrection of the families Pseudoleskeaceae Schimp. and Pylaisiaceae Schimp. (Musci, Hypnales). - Taxon 54: 651-663.

GOLOBOFF, P.A. 1994. NONA: A tree searching program. - Program and documentation. Argentina, Tucumán, published by the author.
HALL, T.A. 1999. BioEdit: a user-friendly biological sequence alignment editor and analysis program for Windows 95/98/NT. - Nucleic Acids Symposium Series 41: 95-98.

HEDENÄS, L, C. REISBORG \& T. HALLINGBÄCK. 2014. Bladmossor/Bryophyta Skirmossor-baronmossor, Hookeria-Anomodon. Nationalnyckeln Sveriges Fl. Fauna. Bladmossor/Bryophyta. Uppsala: ArtDababanken, SLU

HILL, M.O., N. BELL, M.A. BRUGGEMAN-NANNENGA, M. BRUGNÉS, M.J. CANO, J. ENROTH, K.I. FLATBERG, J.-P. FRAHM, M.T. GALLEGO, R. GARILLETI, J. GUERRA, L. HEDENÄS, D.T. HOLYOAK, J. HYVÖNEN, M.S. IGNATOV, F. LARA, V. MAZIMPAKA, J. MUÑOZ \& L. SÖDORSTRÖM. 2006. An annotated Checklist of the mosses of Europe and Macaronesia. - Journal of Bryology 28: 198-267.

HUELSENBECK, J.P., F. RONQUIST \& B. HALL. 2001. MrBayes: bayesian inference of phylogeny. - Bioinformatics 17: 754-755.

IGNATOV M.S., O.M. AFONINA, E.A. IGNATOVA et al. 2006. Checklist of mosses of East Europe and North Asia. - Arctoa 15: 1-130.

KOPONEN T., K. KARTUNEN \& S. PIIPPO. 1995. Suomen vesisammalkasvio. Aqatic bryophytes of Finland. - Bryobrothera 3: 1-86.

KOPONEN, T., P. ISOVIITA \& T. LAMMES. 1977. The bryophytes of Finland: an annotated checklist. - Flora Fennica 6: 1-77.

LIMPRICHT, K.G. 1896. Die Laubmoose. - In: Rabenhorst, L. Kryptogamen-flora von Duetschland, Oesterreich und der Scheiz. Bd. 3. 1448.

LINDBERG, S.O. 1869. Nya mossor. - Öfversigt af Finska VetenskapsSocietetens Förhandlingar 12(2): 76-78.

NIXON, K.C. 1999. Winclada (BETA) ver. 0.9.9. available at http:// www.cladistics.com/about_winc.html.

NYHOLM, E. 1960. Illustrated moss flora of Fennoskandia II. Musci, fasc. 4: $287-408$.

SHAW, J. \& B.H. ALLEN. 2000. Phylogenetic relationships, morphological incongruence, and geographic speciation in the Fontinalaceae (Bryophyta).- Molecular Phylogenetics and Evolution 16: 225-237.

SÖDERSTRÖM, L. (ed.). 1996. Preliminary distribution maps of bryophytes in northwestern Europe. Vol.2. Musci (A-I). Trondheim.

ULVINEN, T. \& K. SYRJÄNEN. 2009. Suomen sammalet levinneisyys eliömaakunnissa. Julk.-In: Laaka-Lindberg, S., S. Antilla \& K. Syrjänen (toim.) Suomen uhanalaiset sammalet. Suomen ypäristökeskus, Helsinki, Ypäristöopas, pp. 309-342.

WELCH, W.H. 1934. Fontinalaceae. - In: Grout, A.J. (ed.) Moss Flora of North America North of Mexico 3: 233-262.

WELCH, W.H. 1960. A monograph of the Fontinalaceae. - The Hague, $357 \mathrm{pp}$. 